\title{
MOLECULAR CHARACTERIZATION OF METHICILLIN-RESISTANT STAPHYLOCOCCUS AUREUS ISOLATED FROM CLINICAL CASES IN EAST ALGERIA
}

\author{
RAHIMA TOUAITIA ${ }^{1,2 *}$, SOUMIA BEKTACHE ${ }^{2}$, NAFISSA BOUTEFNOUCHET ${ }^{1}$, ABDELGHANI DJAHOUDI $^{3}$, \\ MOHAMED BACHTARZI²
}

${ }^{1}$ Department of Biochemistry, Faculty of Sciences, Laboratory of Applied Biochemistry and Microbiology, University of Badji Mokhtar, Annaba, Algeria. ${ }^{2}$ Laboratory of Microbiology, University Hospital Center Mustapha Bacha, Algeria. ${ }^{3}$ Department of Medicine, Laboratory of Microbiology, Faculty of Medicine, University of Badji Mokhtar, Annaba, Algeria.

Email: raya2007microbiologie@hotmail.com

Received: 04 August 2016, Revised and Accepted: 29 September 2016

ABSTRACT

Objective: The purpose of this study is to investigate the methicillin resistance gene, and some virulence factors in methicillin-resistant Staphylococcus aureus (MRSA) isolates by polymerase chain reaction (PCR).

Methods: This study has included 12 MRSA isolates. All isolates were previously identified as S. aureus by a standard microbiological procedure, and a detection of methicillin resistance was realized by phenotypic methods. Following genomic DNA extraction, the presence of $g y r A, m e c A$, lukPV, and tst genes was analyzed by duplex PCR. All retained S. aureus species have been found to contain gyrA gene.

Results: Ten stains have been found to harbor mecA gene indicating it's responsibility for methicillin resistance in those strains. Among the 12 strains, six of which were found to be Panton-Valentine leukocidine positive while none of which has tst gene encoding the toxic shock syndrome toxin.

Conclusion: The pathogenesis of MRSA infections is related to the expression of a wide variety of virulence factors.

Keywords: Methicillin-resistant Staphylococcus aureus, Panton-Valentine leukocidine, Toxic shock syndrome toxin 1, Multidrug resistance, mecA.

(C) 2017 The Authors. Published by Innovare Academic Sciences Pvt Ltd. This is an open access article under the CC BY license (http://creativecommons. org/licenses/by/4. 0/) DOI: http://dx.doi.org/10.22159/ajpcr.2017.v10i1.11856

\section{INTRODUCTION}

Staphylococcus aureus, including methicillin-resistant S. aureus (MRSA), is one of the most prevalent human pathogens isolated from hospitalized patients worldwide and its importance in community settings continues to increase [1]. In 1950, the emergence of antibiotic-resistant strains provided a better understanding of epidemiology of S. aureus disease [2]. It often asymptomatically colonizes the skin and mucous membranes of healthy individuals, in particular the anterior nares [3].

The clinical importance of MRSA is attributed to notable virulence factors, surface proteins, toxins, and enzymes as well as rapid development of drug resistance [4]. Some of these virulence factors are known to cause or to be associated with specific diseases, such as Panton-Valentine leukocidine (PVL) in necrotizing pneumonia and toxic shock syndrome toxin (TSST) in skin diseases [5].

The importance of assessing the presence and combination of virulence factors associated to MRSA infections has been recently emphasized by different authors [6] supporting the idea that the development of infections could be related to strain-specific pathogenic attributes.

This study was conducted so as to investigate the phenotypic and genotypic characterization of MRSA involved in east Algeria. The confirmation of the species $S$. aureus was performed by amplifying the gene gyrA. Resistance to methicillin was performed by detection of mecA gene and several virulence factors including toxin of the PVL coding gene as well as TSST coding gene were searched by polymerase chain reaction (PCR).

\section{METHODS}

Identification of $S$. aureus strains

Twelve strains of $S$. aureus resistant to methicillin from Annaba Health establishment were included in this study from clinical sources (pus, urine, and vaginal samples). S. aureus strains were grown on blood agar at $37^{\circ} \mathrm{C}$. After overnight incubation, strains were examined by Gramstain and using catalase and coagulase tests as described previously [7]. Isolates were also tested using the Pastorex Staph Plus latex (Bio-Rad) for identification of $S$. aureus.

\section{Antimicrobial susceptibility testing}

Antibiotic resistance was determined by the disk diffusion method (Bio-Rad, France) in Mueller-Hinton agar (Bio-Rad) according to the recommendations outlined by the Comite de l'Antibiogramme de la SociétéFrançaise de Microbiologie 2013.

Detection of methicillin resistance was realized by phenotypic methods as described previously [8].

The tested antibiotics were penicillin G (PG - $6 \mu \mathrm{g}$ ), oxacillin $(\mathrm{Ox}-5 \mu \mathrm{g})$, cefoxitin (FOX - $30 \mu \mathrm{g}$ ), gentamicin (GM - $15 \mu \mathrm{g}$ ), tobramycin (TOB - $6 \mu \mathrm{g}$ ), kanamycin (K - $30 \mathrm{UI})$, tetracycline $(\mathrm{TE}-30 \mu \mathrm{g})$, clindamycin $(\mathrm{CM}-2 \mu \mathrm{g})$, erythromycin $(\mathrm{E}-15 \mu \mathrm{g})$, pristinamycin (PR - $15 \mu \mathrm{g}$ ) chloramphenicol (C - $30 \mu \mathrm{g}$ ), ofloxacin (OFX $-5 \mu \mathrm{g}$ ), fusidic acid (FA - $10 \mu \mathrm{g}$ ), vancomycin (VA $-30 \mu \mathrm{g})$, teicoplanin (TEC - $30 \mu \mathrm{g}$ ), rifampicin (RA - $50 \mu \mathrm{g}$ ), and trimethoprimsulfamethoxazole (cotrimoxazole) (SXT - 1.25/23.75 $\mu \mathrm{g}$ ).

\section{Genetic characterization}

Bacterial DNA extraction

The extraction technique was simplified by directly suspending $5-10$ colonies in $1 \mathrm{ml}$ of water, centrifuged at $13,000 \mathrm{~g}$ for 10 minutes, discards the supernatant and recover the pellet, resuspended in $300 \mu \mathrm{l}$ of water, and centrifuged the suspensions for 10 minutes at $100^{\circ} \mathrm{C}$. The DNA was released by centrifugation at $13,000 \mathrm{~g}$ for 10 minutes in the supernatant.The collected DNA was visualized after electrophoresis on $1.5 \%$ agarose gels containing éthidium bromide. 
Duplex PCR amplification of gyrA and mecA genes

PCR amplification of the gyrA gene in $S$. aureus acts as an internal control, allowing the quality of the DNA extraction and amplification for each sample [9]. The presence of the $m e c A$ gene was detected following a PCR procedure described elsewhere [10].

\section{Duplex PCR amplification of luk-PV and tst genes}

The 12 MRSA strains isolated were of object research of the gene encoding leukocidin Panton-Valentine toxin $L u k-P V$ and the gene encoding the TSST tst using specific primers as described previously $[11,12]$.

\section{RESULTS}

Precise identification of $S$. aureus is important for successful implementation of a staphylococcal infections control program. Therefore, according to the phenotypic, biochemical properties as well as by amplification of the gyrA gene, all of the isolates obtained in this study were identified as $S$. aureus.

Antibiotic resistance patterns of the MRSA strains isolated shown in Fig. 1

Among the 12 strains of MRSA, 10 were mecA positive, indicating that mecA is responsible for methicillin resistance in those strains (Fig. 2).

Detection of PVL toxin by amplification of the gene $l u k-P V$ from extracted DNA of the strains reveled that five strains from 12 were positive for amplification of the $533 \mathrm{~Pb}$ fragment of luk-PVgene.While none strain had the gene tst encoding the TSST (Fig. 3)

\section{DISCUSSION}

The multidrug resistance of MRSA has become increasingly a major problem and responsible for most of the hospital-acquired infections. Many virulence factors are associated with MRSA that enable them to cause disease [13]. The aim of this study was to investigate the methicillin resistance gene and some virulence factors in MRSA isolates by PCR.

The obtained results showed that MRSA isolates exhibited low resistance to chloramphenicol and trimethoprim/sulfamethoxazole. This supports the potential utility of chloramphenicol and trimethoprim/sulfamethoxazole as empiric treatment agents for MRSA in Algeria.

However, almost of strains were resistant to gentamicin, tobramycin, tetracycline, and ofloxacin. Fortunately, none of this MRSA strains was resistant to vancomycin, teicoplanin, and pristinamycin. All strains showed also a high resistance to kanamycin.

Genotypic detection of mecA is widely used as a reference standard for identification of MRSA, whether used as a primary test or for confirmation [14]. In our study, 10 strains were harboring the gene тесA responsible for methicillin resistance. The two remaining strains were $m e c A$ negative must be methicillin resistant by implication of some other mechanism [14] and could thus be classified as producers of $\beta$-lactamase or often identified as borderline oxacillin-resistant $S$. aureus or, more rarely, moderately resistant $S$. aureus strains [15].

Many virulence factors are associated with MRSA that enable them to cause disease.

In our study, six MRSA strains were produced The PVL toxin which was investigated further by testing 12 strains of MRSA to lukPV PCR; two of them were mecA negative. In the previous studies on the general population in Algeria, rates of PVL+ strains were $67.2 \%$ in 2006 [16] down to $35.7 \%$ [9] and $29.7 \%$ [17]. Other studies were reported lower

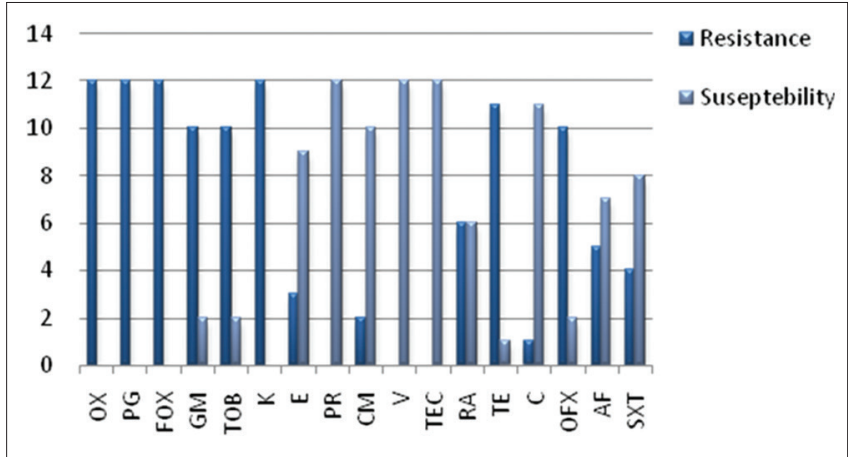

Fig. 1: Antibiotic-resistance profile of methicillin resistant Staphylococcus aureus strains

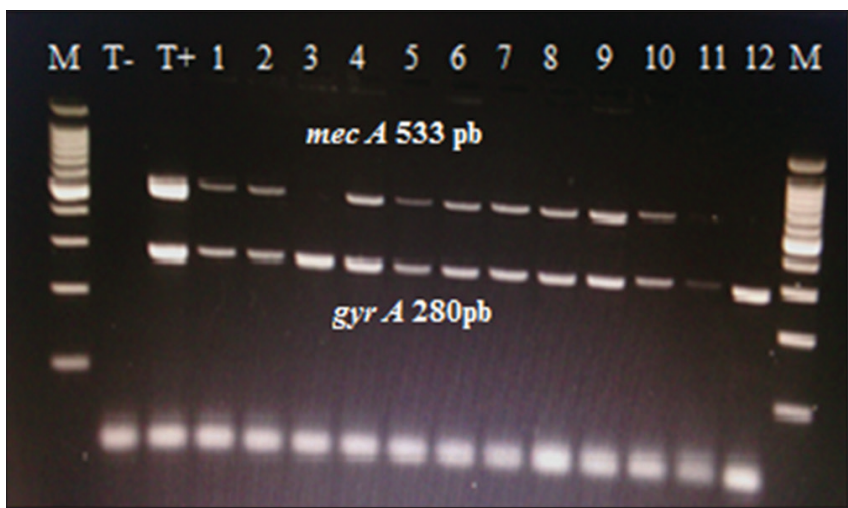

Fig. 2: Electrophoresis on agarose gel of $m e c A$ and gyrA genes. Lane 1-12: The polymerase chain reaction products of methicillin resistant Staphylococcus aureus studied DNA samples. T: Negative control. T+: Positive controls. M: 100 bp DNA marker

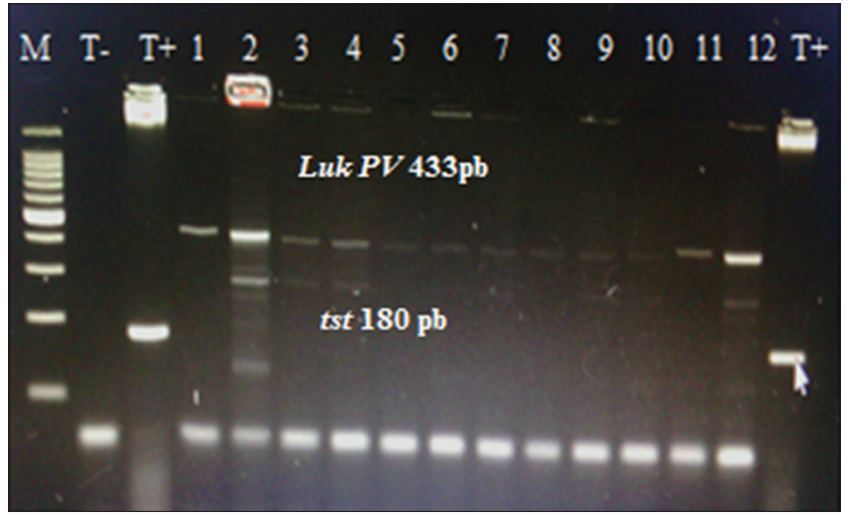

Fig. 3: Electrophoresis on agarose gel of $l u k-P V$ and $t s t$ genes. Lane 1-12: The polymerase chain reaction products of methicillin resistant Staphylococcus aureus studied DNA samples. T: Negative control. T+: Positive controls. M: 100 bp DNA marker

rates PVL positive MRSA such as $15 \%$ in the Netherlands [18] and $0.7 \%$ in Japan [19].

The tst PCR assay of MRSA strains showed that none of these strains generated positive results. Same results were reported in Nigerian study [20] and other in Tunisia [21].

However, El-Ghodban et al. in Libya reported a frequency of tst gene isolation, only $7.5 \%$ in 40 clinical isolates [22]. Teyhoo et al., in Iran, detected $14.3 \%$ and $20 \%$ tst gene carriage in clinical isolates [23]. 


\section{CONCLUSION}

The pathogenesis of MRSA infections is related to the expression of a wide variety of virulence factors, including PVL and TSST toxins, which might be considered as potential threats especially that most of them have multidrug resistance, rendering it difficult to treat.

\section{ACKNOWLEDGMENT}

This study was supported by grants from the Algerian Ministry of High Education and scientific research.

\section{REFERENCES}

1. Al Laham N, Mediavilla JR, Chen L, Abdelateef N, Elamreen FA, Ginocchio CC, et al. MRSA clonal complex 22 strains harboring toxic shock syndrome toxin (TSST-1) are endemic in the primary hospital in Gaza, Palestine. PLoS One 2015;10(3):e0120008.

2. Ramazanzadeh R, Talvar HM, Mirzaii M, Hasheminasab S, Narenji H. Investigating prevalence of pathogenic genes (ETA and TSST-1) in Staphylococcus aureus isolated from different wards of the hospitals by PCR method. Int J Sci World 2015;3(2):239-43.

3. Jenkins A, Diep BA, Mai TT, Vo NH, Warrener P, Suzich J, et al. Differential expression and roles of Staphylococcus aureus virulence determinants during colonization and disease. MBio 2015;6(1):e02272-14.

4. Sabouni F, Mahmoudi S, Bahador A, Pourakbari B, Sadeghi RH, Ashtiani MT, et al. Virulence factors of Staphylococcus aureus isolates in an Iranian referral children's hospital. Osong Public Health Res Perspect 2014;5(2):96-100.

5. Mertz PM, Cardenas TC, Snyder RV, Kinney MA, Davis SC, Plano LR. Staphylococcus aureus virulence factors associated with infected skin lesions: Influence on the local immune response. Arch Dermatol 2007;143(10):1259-63.

6. Zecconi A, Cesaris L, Liandris E, Daprà V, Piccinini R. Role of several Staphylococcus aureus virulence factors on the inflammatory response in bovine mammary gland. Microb Pathog 2006;40(4):177-83.

7. Duguid JP. Staphylococcus: Cluster-forming gram-positive cocci. In: Collee JG, Duguid JP, Fraser AG, Marmion BP, editors. Practical Medical Microbiology. 13 ${ }^{\text {th }}$ ed. Edinburgh: Churchill Livingstone; 1989. p. 303-16.

8. Touaitia R, Boutefnouchet N, Djahoudi A. Prevalence of methicillinresistant Staphylococcus aureus and/or intermediate susceptibility to vancomycin isolated from private laboratories in Annaba "Algeria". J Chem Pharm Res 2015;7(5):780-6.

9. Antri K, Rouzic N, Boubekri I, Dauwalder O, Beloufa A, Ziane H, et al. High prevalence of community - And hospital-acquired infections of methicillin-resistant Staphylococcus aureus containing Panton-Valentine leukocidin gene in Algiers. Pathol Biol (Paris) 2010;58(2):e15-20.

10. Sung JM, Lloyd DH, Lindsay JA. Staphylococcus aureus host specificity: Comparative genomics of human versus animal isolates by multi-strain microarray. Microbiology 2008;154:1949-59.

11. Saïd-Salim B, Mathema B, Braughton K, Davis S, Sinsimer D, Eisner $\mathrm{W}$, et al. Differential distribution and expression of Panton-Valentine leucocidin among community-acquired methicillin-resistant Staphylococcus aureus strains. J Clin Microbiol 2005;43(7):3373-9.

12. Schlievert PM, Case LC. Molecular analysis of staphylococcal superantigens. Methods Mol Biol 2007;391:113-26.

13. El-Gayar M, Aboulwafa M, Aboshanab K, Hassouna N. Virulence characters of some methicillin resistant Staphylococcus aureus isolates. Arch Clin Microbiol 2014;5(4):3.

14. Chambers HF. Methicillin resistance in staphylococci: Molecular and biochemical basis and clinical implications. Clin Microbiol Rev 1997;10(4):781-91.

15. Stegger M, Andersen PS, Kearns A, Pichon B, Holmes MA, Edwards G, et al. Rapid detection, differentiation and typing of methicillin-resistant Staphylococcus aureus harbouring either mecA or the new mecA homologue mecA(LGA251). Clin Microbiol Infect 2012;18(4):395-400

16. Ramdani-Bouguessa N, Bes M, Meugnier H, Forey F, Reverdy ME, Lina G, et al. Detection of methicillin-resistant Staphylococcus aureus strains resistant to multiple antibiotics and carrying the PantonValentine leukocidin genes in an Algiers hospital. Antimicrob Agents Chemother 2006;50(3):1083-5.

17. Ouchenane Z, Smati F, Rolain JM, Raoult D. Molecular characterization of methicillin-resistant Staphylococcus aureus isolates in Algeria. Pathol Biol (Paris) 2011;59(6):e129-32.

18. Adedeji A, Weller TM, Gray JW. MRSA in children presenting to hospitals in Birmingham, UK. J Hosp Infect 2007;65(1):29-34.

19. Yanagihara K, Araki N, Watanabe S, Kinebuchi T, Kaku M, Maesaki S, et al. Antimicrobial susceptibility and molecular characteristics of 857 methicillin-resistant Staphylococcus aureus isolates from 16 medical centers in Japan (2008-2009): Nationwide survey of communityacquired and nosocomial MRSA. Diagn Microbiol Infect Dis 2012;72(3):253-7

20. Ghebremedhin B, Olugbosi MO, Raji AM, Layer F, Bakare RA, König B, et al. Emergence of a community-associated methicillinresistant Staphylococcus aureus strain with a unique resistance profile in Southwest Nigeria. J Clin Microbiol 2009;47(9):2975-80.

21. Nejma MB, Mastouri M, Jrad BB, Nour M. Characterization of ST80 Panton-Valentine leukocidin positive community-acquired methicillin resistant Staphylococcus aureus clone in Tunisia. Diagn Microbiol Infect Dis 2013;77(1):20-4.

22. El-Ghodban A, Ghenghesh KS, Márialigeti K, Esahli H, Tawil A. PCR detection of toxic shock syndrome toxin of Staphylococcus aureus from Tripoli, Libya. J Med Microbiol 2006;55:179-82.

23. Teyhoo M, Mobaiyen H, Amirmozafari N, Moaddab SR, Monesrast S. Prevalence of toxic shock syndrome toxin I producing clinical isolates of Staphylococcus aureus strains isolated from hospitals in Tabriz, Iran. Int J Biosci 2014;4(9):169-76. 